\title{
Characterization of different $\mathbf{G}$ protein coupling properties of $\mathbf{C B}_{\text {I }}$ and $\mathrm{CB}_{2}$ cannabinoid receptors and GPR55 receptor using BRET Pál Gyombolai, Gábor Turu and László Hunyady*
}

\author{
Address: Department of Physiology, Semmelweis University, Faculty of Medicine, 1082 Budapest, Hungary \\ Email: László Hunyady* - laszlo.hunyady@eok.sote.hu \\ * Corresponding author
}

\begin{abstract}
from I5th Scientific Symposium of the Austrian Pharmacological Society (APHAR) Joint meeting with the Hungarian Society of Experimental and Clinical Pharmacology (MFT) and the Slovenian Pharmacological Society (SDF)

Graz, Austria. 19-2I November 2009

Published: 12 November 2009

BMC Pharmacology 2009, 9(Suppl 2):A43 doi:10.1186/I47I-2210-9-S2-A43
\end{abstract}

This abstract is available from: http://www.biomedcentral.com/I47I-22/0/9/S2/A43

(c) 2009 Gyombolai et al; licensee BioMed Central Ltd.

\section{Background}

$\mathrm{CB}_{1}$ and $\mathrm{CB}_{2}$ cannabinoid receptors are $\mathrm{G}$ protein-coupled receptors which have been described to couple mainly to the $\mathrm{G}_{\mathrm{i} / \mathrm{o}}$ subfamily of $\mathrm{G}$ proteins. However, in some cell types and upon stimulation with certain cannabinoid agonists, activation of other $G$ protein subtypes has also been observed. GPR55 is an orphan G protein-coupled receptor which has been suggested to be a novel member of the cannabinoid receptor family.

\section{Methods}

In this study we wanted to characterize the $\mathrm{G}$ protein activation properties of the two known cannabinoid receptors and GPR55 following stimulation with different cannabinoid ligands, using bioluminescence resonance energy transfer (BRET). We monitored the activation of different $G$ protein subtypes $\left(G_{o^{\prime}}, G_{q}, G_{s}\right.$ or $\left.G_{12}\right)$ using Renilla luciferase-tagged wild type or chimeric $\mathrm{G} \alpha_{\mathrm{o}}$ subunits (i.e. $\mathrm{G} \alpha_{0}$ with the C-terminal 5 amino acids replaced with those of $\mathrm{G}_{\mathrm{q}^{\prime}} \mathrm{G} \alpha_{\mathrm{s}}$ or $\mathrm{G} \alpha_{12}$, respectively) co-expressed with EYFP-tagged $\alpha_{1} \alpha_{11}$ subunit and the receptor in $\mathrm{CHO}$ cells.

\section{Results}

We found that $\mathrm{CB}_{1}$ was able to activate all four subtypes of $\mathrm{G}$ proteins, with different pharmacokinetic properties, following stimulation by non-selective (WIN55 and 2-AG) or $\mathrm{CB}_{1}$-selective (ACEA) cannabinoid agonists. Basal activity of $\mathrm{CB}_{1}$ could also be detected with $\mathrm{G}_{\mathrm{o}}$ and $\mathrm{G}_{12}$ subtypes, as the $\mathrm{CB}_{1}$ inverse agonist $\mathrm{AM} 251$ caused significant
BRET increase (i.e. G protein subunit association) when tested with these $G$ proteins. In contrast, $\mathrm{CB}_{2}$ showed no $\mathrm{G}$ protein activation other than $\mathrm{G}_{\mathrm{O}^{\prime}}$ upon either WIN55 or 2-AG stimuli. Stimulation of GPR55 with WIN55, 2-AG or AM251 did not alter the activity of the tested $G$ proteins even at considerably high ligand concentrations. 